\title{
TREATMENT OF RUBBER GLOVE WASTEWATER BY ULTRAFILTRATION
}

\author{
P.S. Yap ${ }^{1}$, Shaliza Ibrahim ${ }^{1 *}$, K.B. Ang ${ }^{2}$ \\ ${ }^{1}$ Department of Civil Engineering, University of Malaya, 50603 Kuala Lumpur, Malaysia \\ ${ }^{2}$ Memfil Sdn Bhd, Shah Alam, Malaysia \\ * Corresponding author (email: shaliza@um.edu.my)
}

\begin{abstract}
The feasibility of using flat-sheet ultrafiltration polyethersulfone (PES) membranes for treatment of effluent from a rubber glove factory has been investigated. Membranes of molecular weight cut-off (MWCO) $100 \mathrm{kDa}$ and $10 \mathrm{kDa}$ were operated in cross-flow filtration to evaluate the efficiency of rejections of certain selected parameters in the wastewater. The membrane operation was carried out at a condition of $1.0 \mathrm{bar}$ for the inlet pressure and 0.2 bar for the outlet pressure. The parameters tested were chemical oxygen demand (COD), total suspended solids (TSS), ammoniacal nitrogen (AN), total Kjeldahl nitrogen (TKN), turbidity, $\mathrm{pH}$, colour and trace metals. In addition, COD tests were also carried out for dead-end filtration of filter paper for comparison. The overall best results came from cross-flow filtration of $10 \mathrm{kDa}$ membranes, where high percentage of rejection was recorded for COD $(73.07 \%)$, TSS $(90.61 \%)$ and turbidity $(96.60 \%)$. The results also showed that the permeate produced can be safely discharged into watercourses in compliance with the legal requirements of Malaysia's environmental laws and regulations.

(Keywords: Flat sheet PES membranes, MWCO $100 \mathrm{kDa}$ and $10 \mathrm{kDa}$, ultrafiltration, rubber glove
\end{abstract} wastewater)

\section{INTRODUCTION}

Malaysia is the fourth largest rubber producer in the world, the fifth-largest rubber consumer and is among the biggest exporters of rubber products globally. Furthermore, Malaysia is the biggest producer of rubber gloves in the world [1].

However, the growth of the rubber products manufacturing industry in Malaysia has not only contributed to the country's significant economic growth, but also posed adverse environmental damage because of the discharge of high amount of wastewater [2].

The rubber glove wastewater produced needs to be treated so that it can comply with environmental laws before being discharged into rivers. One of the many ways which could be implemented is to use membrane technology.

Although membrane technologies have a long history [3], their significant improvements only come into attention in the last twenty years.

Despite that fact that membranes do have their own disadvantages, especially in terms of costs, they still remain a very much recommended solution, mainly because of the constant technological advancement, which makes the benefits far outweigh any drawbacks [4].
Breslau \& Buckley [5], quoted by Ersu et al [6], made a significant breakthrough when they discovered that by using polyethersulfone (PES) flat-sheet and polysulfone hollow fiber membranes, a concentration level of up to $40 \%$ can be expected in "white-water" containing styrene-butadiene latex, thus reducing the wastewater volume and subsequently saving disposal costs.

This particular laboratory scale project serves to determine the feasibility of using flat-sheet polyethersulfone (PES) ultrafiltration membranes for the treatment of rubber glove wastewater. The PES membranes used have molecular weight cut-off (MWCO) of $100 \mathrm{kDa}$ and $10 \mathrm{kDa}$, respectively.

\section{MATERIAL AND METHODS}

The raw rubber glove wastewater was collected from a rubber glove factory in Ipoh, Perak, Malaysia. The samples were then preserved by storing them in a cold room. The analysis of the sample's characteristics were carried out to obtain accurate initial readings. Subsequently, membrane experimental run was done, and the quality of the permeate was analyzed to determine the efficiency of cross-flow ultrafiltration treatment. In addition, dead-end filtration was also performed by using Whatman filter paper to compare the removal efficiency. 


\section{UF membrane and experimental apparatus}

The specifications of the flat-sheet membranes used in this work are presented in Table 1.

Table 1: Membrane specifications

\begin{tabular}{|c|c|c|}
\hline Type & $\begin{array}{l}\text { ULTRAN Lab- } \\
\text { Mini PES } 100\end{array}$ & $\begin{array}{l}\text { ULTRAN Lab- } \\
\text { Mini PES } 10\end{array}$ \\
\hline $\begin{array}{l}\text { Membrane } \\
\text { material }\end{array}$ & $\begin{array}{l}\text { Polyethersulfon } \\
\text { e (PES) }\end{array}$ & $\begin{array}{l}\text { Polyethersulfon } \\
\text { e (PES) }\end{array}$ \\
\hline Cut Off & $100 \mathrm{kDa}$ & $10 \mathrm{kDa}$ \\
\hline $\begin{array}{l}\text { Membrane } \\
\text { Area }\end{array}$ & $0.1 \mathrm{~m}^{2}$ & $0.1 \mathrm{~m}^{2}$ \\
\hline Screens & Polypropylene & Polypropylene \\
\hline Adhesives & Silicone & Silicone \\
\hline $\begin{array}{l}\text { Preservativ } \\
\mathrm{e}\end{array}$ & $\begin{array}{l}\text { Glycerol / } \\
\mathrm{NaN}_{3} \text { (sodium } \\
\text { azide) }\end{array}$ & $\begin{array}{l}\text { Glycerol / } \\
\mathrm{NaN}_{3} \text { (sodium } \\
\text { azide) }\end{array}$ \\
\hline Torque & $40 \mathrm{Nm}$ & $50 \mathrm{Nm}$ \\
\hline
\end{tabular}

1. Membrane holder

2. Peristaltic pump

3. Flat-sheet PES membrane (100 kDa and $10 \mathrm{kDa}$ )

4. Thermometer

5. $\mathrm{pH}$ meter

6. $\mathrm{NaOH}$ solution $(0.1 \mathrm{~N})$

7. Distilled water

8. Rubber glove wastewater

9. Heater

10. Stop-watch

11. Torque adjuster

12. Adjustable tube-clip (Backpressurevalve)

\section{Wastewater and Permeate Analysis}

The analysis of wastewater and permeate was done according to APHA method [7]. Parameters that were tested include COD, TSS, AN, TKN, turbidity and colour.

\section{RESULTS AND DISCUSSION}

\section{UF Membrane Characteristics}

The characteristic performance of $100 \mathrm{kDa}$ and $10 \mathrm{kDa}$ polyethersulfone (PES) membranes can be analysed from Figures 1, 2, 3 and 4. Figures 1 and 3 show that the flux versus time was almost a straight horizontal line for both the 100 $\mathrm{kDa}$ and $10 \mathrm{kDa}$ membranes. This means that there is very little fouling on the membranes from the usage of rubber glove wastewater. In other words, there is no chemical interaction between rubber glove wastewater and the membranes which may affect the permeate results. This can most probably be attributed to the good working conditions of the new membranes. Although there was a slight drop in the flux with respect to time initially, but, over a longer period, it has managed to reach a satisfactory constant level, which is a desirable case.

Flux versus TMP (transmembrane pressure) for both $100 \mathrm{kDa}$ and $10 \mathrm{kDa}$ was found to be a linearly related, or directly-proportional, as indicated by the plots in Figures 2 and 4. Hence, both $100 \mathrm{kDa}$ and $10 \mathrm{kDa}$ are fit to be used and the results from their applications are valid.

It should be noted that the flux obtained from 10 $\mathrm{kDa}$ is smaller than flux from $100 \mathrm{kDa}$. Lower flux means lower permeability. Since $10 \mathrm{kDa}$ is capable of rejecting smaller size macromolecules that cannot be removed by $100 \mathrm{kDa}$, therefore it is also expected that permeation rate for $10 \mathrm{kDa}$ is small.

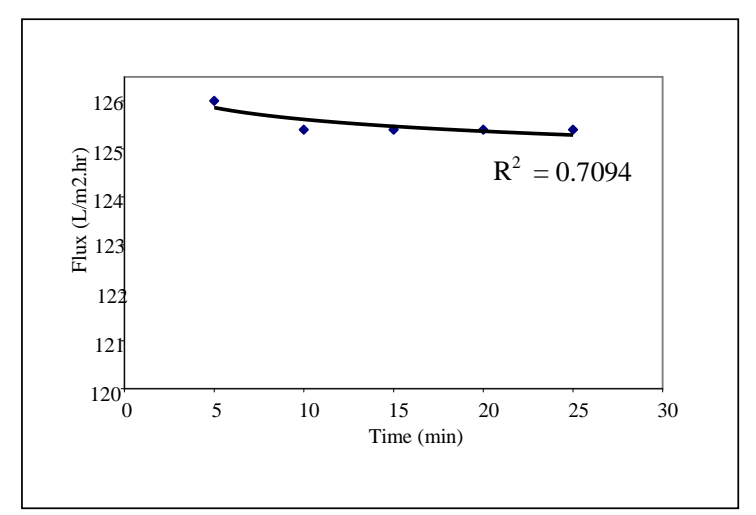

Figure 1 Flux versus time for $100 \mathrm{kDa}$ PES membrane

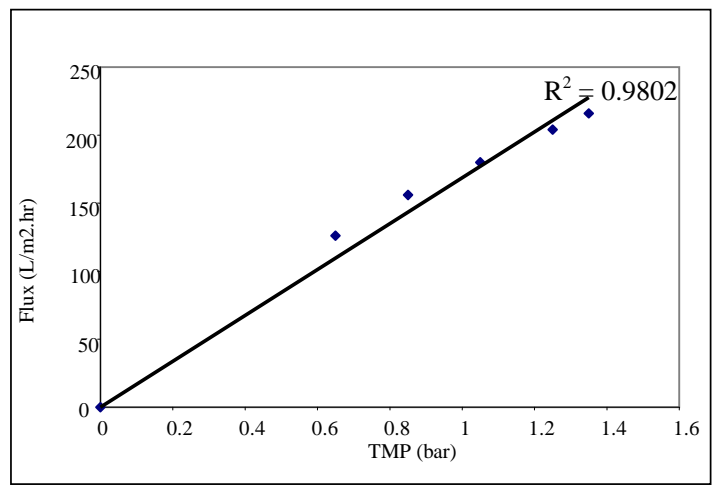

Figure 2 Flux versus TMP for $100 \mathrm{kDa}$ PES membrane 


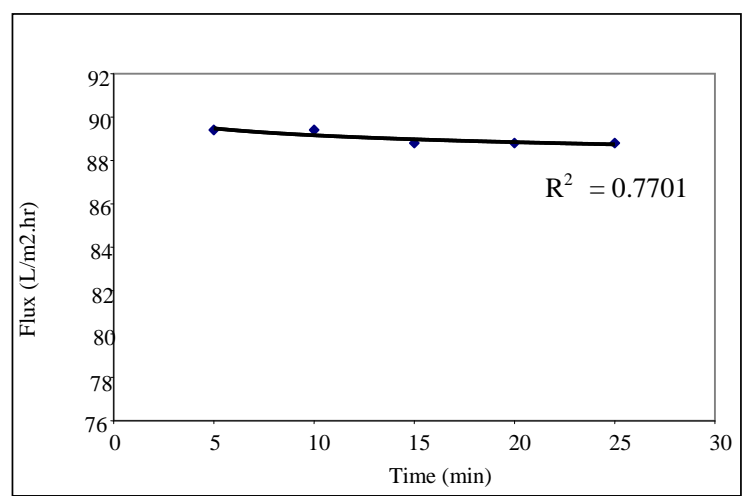

Figure 3 Flux versus time for $10 \mathrm{kDa}$ PES membrane

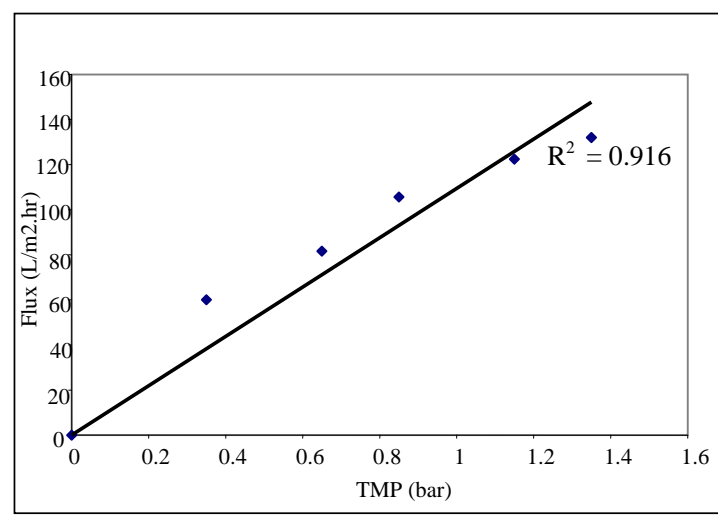

Figure 4 Flux versus TMP for $10 \mathrm{kDa}$ PES membrane

\section{Rejection performance}

Tables 2 and $\mathbf{3}$ show the COD results. Interestingly, in the initial runs for both membranes, COD increased substantially, but subsequent runs showed the COD being reduced by the membrane treatment.

Table 2 COD summary for $100 \mathrm{kDa}$ PES membrane (Cross-Flow Filtration)

\begin{tabular}{|c|c|c|c|}
\hline $\begin{array}{c}\text { Experimen } \\
\text { t No. }\end{array}$ & \multicolumn{2}{|c|}{ COD (mg/L) } & Percentag \\
\cline { 2 - 3 } & $\begin{array}{c}\text { Rubber } \\
\text { glove } \\
\text { wastewate } \\
\text { r (feed) }\end{array}$ & $\begin{array}{c}\text { Permeat } \\
\text { e for } \\
100 \mathrm{kDa}\end{array}$ & $\begin{array}{c}\text { rejection } \\
(\%)\end{array}$ \\
\hline 1 & 70.74 & 390.38 & - \\
\hline 2 & 68.50 & 30.14 & 56.00 \\
\hline 3 & 78.12 & 37.20 & 52.38 \\
\hline 4 & 75.66 & 32.98 & 56.41 \\
\hline $\begin{array}{c}\text { Average of } \\
2,3 \text { \& 4 }\end{array}$ & 74.09 & 33.44 & 54.93 \\
\hline
\end{tabular}

Table 3 COD summary for $10 \mathrm{kDa}$ PES membrane (Cross-Flow Filtration)

\begin{tabular}{|c|c|c|c|}
\hline \multirow{2}{*}{$\begin{array}{c}\text { Experimen } \\
\text { t No. }\end{array}$} & \multicolumn{2}{|c|}{$\mathrm{COD}(\mathrm{mg} / \mathrm{L})$} & \multirow{2}{*}{$\begin{array}{c}\text { Percentag } \\
\text { e of } \\
\text { rejection } \\
(\%)\end{array}$} \\
\hline & $\begin{array}{c}\text { Rubber } \\
\text { glove } \\
\text { wastewate } \\
\text { r (feed) }\end{array}$ & $\begin{array}{c}\text { Permeat } \\
\text { e for } \\
10 \mathrm{kDa}\end{array}$ & \\
\hline 1 & 66.64 & 96.04 & - \\
\hline 2 & 73.32 & 22.56 & 69.23 \\
\hline 3 & 72.52 & 17.64 & 75.68 \\
\hline 4 & 71.40 & 18.36 & 74.29 \\
\hline $\begin{array}{c}\text { Average of } \\
2,3 \& 4\end{array}$ & 72.41 & 19.52 & 73.07 \\
\hline
\end{tabular}

The first experiment value was not taken into account for average calculation of COD. It is suspected that the initial increase of COD in the permeate is due to the preservative of the new membranes, namely glycerol and $\mathrm{NaN}_{3}$. The preservatives are necessary because they prevent the membranes from being dry before being opened for used. Therefore, when the experiment was first carried out, the glycerol was flushed out into the permeate. Thus, for new membranes it is strongly recommended that it be flushed out entirely before use.

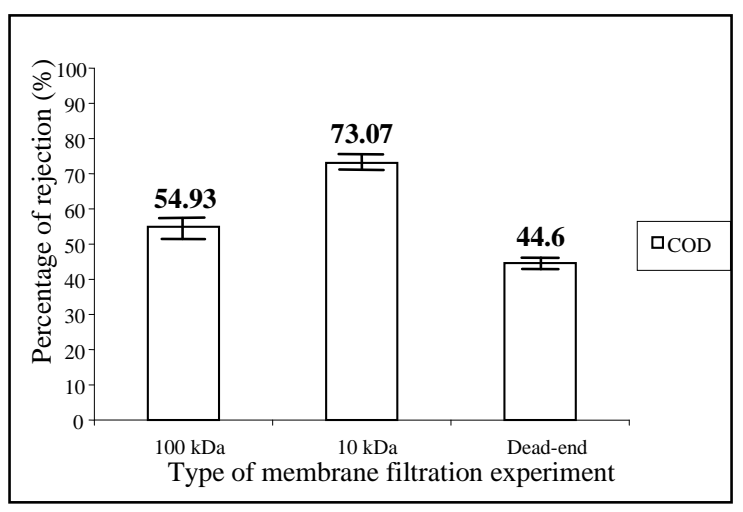

Figure 5 Comparison of COD's rejection performance between cross-flow and dead-end filtration

In terms of performance, $10 \mathrm{kDa}$ is more efficient than $100 \mathrm{kDa}$ with average rejection rates of $73.07 \%$ and $54.93 \%$, respectively. This result is satisfactory theoretically because 10 $\mathrm{kDa}$ is capable of reject smaller macromolecules (smaller molecular weight) as compared to 100 $\mathrm{kDa}$. By comparison, a dead-end filtration using glass-fibre paper rejected only about $44.60 \%$ COD (Fig. 5). 
The $10 \mathrm{kDa}$ PES membrane performed better than the $100 \mathrm{kDa}$ for all five parameters tested, particularly for COD (73.07\%), TSS $(90.61 \%)$ and turbidity (96.60\%) (Fig. 6). AN and TKN, however, registered comparatively low percentage of removal for both $100 \mathrm{kDa}$ and 10 $\mathrm{kDa}$.

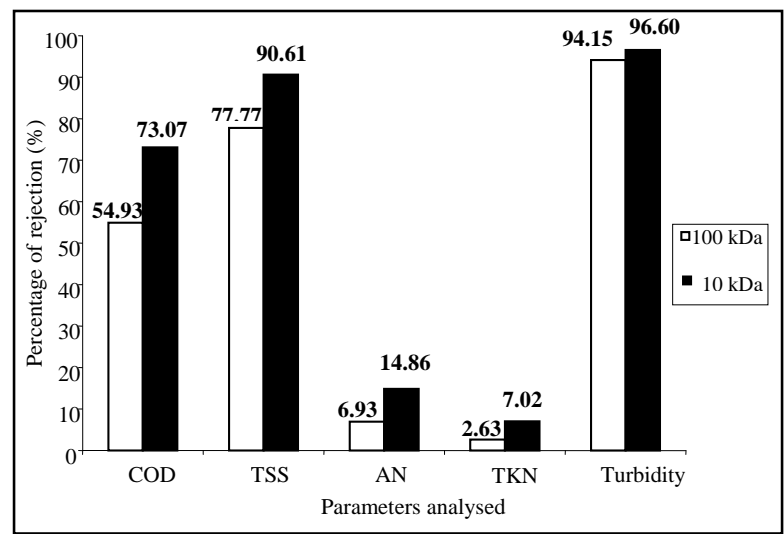

Figure 6 Comparison of selected parameter's rejection performance between $100 \mathrm{kDa}$ and 10 $\mathrm{kDa}$ PES membrane

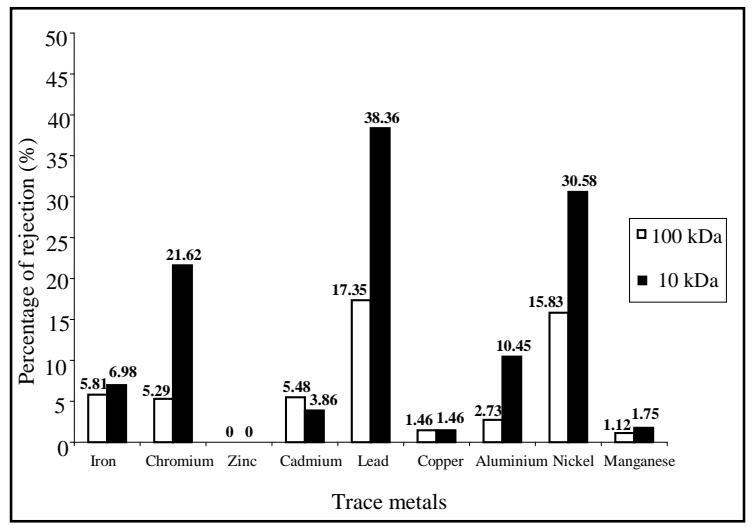

Figure 7 Comparison of trace metal's rejection performance between $100 \mathrm{kDa}$ and $10 \mathrm{kDa}$ PES membranes

The rejection performance for most trace metals can be considered low, as shown in Fig. 7. Meanwhile, the trace metal concentrations in the rubber glove wastewater and permeates from 100 $\mathrm{kDa}$ and $10 \mathrm{kDa}$ are shown in Table 4. The concentrations of these trace metals were determined using Inductively Coupled Plasma (ICP). Permeate from $10 \mathrm{kDa}$ showed higher removal of iron, chromium, lead, aluminium, nickel and manganese as compared to permeate from $100 \mathrm{kDa}$. However, there were some anomalies recorded. For example, zinc was undetectable in the experiment. Besides, cadmium was rejected more effectively by 100 $\mathrm{kDa}$ instead of $10 \mathrm{kDa}$. Meanwhile, the copper's rejection performance was the same for permeate from $100 \mathrm{kDa}$ and $10 \mathrm{kDa}$ membranes.

Table 4 Trace metals concentration in rubber glove wastewater and permeate from $100 \mathrm{kDa}$ and $10 \mathrm{kDa}$

\begin{tabular}{|l|c|c|c|}
\hline $\begin{array}{l}\text { Trace } \\
\text { Metals }\end{array}$ & $\begin{array}{l}\text { Rubber } \\
\text { glove } \\
\text { wastewate } \\
\text { r(ppm) } \\
\text { (Average } \\
\text { from 3 } \\
\text { replication } \\
\text { s) }\end{array}$ & $\begin{array}{l}\text { Permeate } \\
\text { from } \\
100 \mathrm{kDa} \\
\text { (ppm) } \\
\text { (Average } \\
\text { from 3 } \\
\text { replication } \\
\text { s) }\end{array}$ & $\begin{array}{l}\text { Permeate } \\
\text { from } \\
10 \mathrm{kDa} \\
(\mathrm{ppm}) \\
\text { (Average } \\
\text { from 3 } \\
\text { replicatio } \\
\mathrm{n})\end{array}$ \\
\hline Ferum & 1.720 & 1.620 & 1.600 \\
\hline $\begin{array}{l}\text { Chromiu } \\
\mathrm{m}\end{array}$ & 0.680 & 0.644 & 0.533 \\
\hline Zinc & $\mathrm{ND}$ & $\mathrm{ND}$ & $\mathrm{ND}$ \\
\hline Cadmium & 0.621 & 0.587 & 0.597 \\
\hline Lead & 2.19 & 1.81 & 1.35 \\
\hline Copper & 2.050 & 2.020 & 2.020 \\
\hline $\begin{array}{l}\text { Aluminiu } \\
\mathrm{m}\end{array}$ & 1.100 & 1.070 & 0.985 \\
\hline Nickel & 1.20 & 1.01 & 0.833 \\
\hline $\begin{array}{l}\text { Mangane } \\
\text { se }\end{array}$ & 0.802 & 0.793 & 0.788 \\
\hline
\end{tabular}

NOTE: ND means not detectable because of too low concentration

Thus, ultrafiltration may not be a feasible analysis for trace metals as ultrafiltration's main purpose is for macromolecules separations. In lieu of that, it is recommended that nanofiltration (NF) and reverse osmosis (RO) to be used for appropriate treatments of trace metals because they involve rejection in the ionic range. In fact, past research had revealed that NF and RO are suitable membrane technologies whereby they can remove not just heavy metals but also nitrates, hardness, organics and TDS [8].

\section{Permeate Quality}

Table 5 shows that the concentration of COD, TSS, AN and TKN for permeate from $100 \mathrm{kDa}$ membrane are well below the permitted effluent limits of the regulation. The $\mathrm{pH}$ is also within the range of acceptance. Even though the initial characteristics of the wastewater were also in compliance with the regulation, but, after 100 $\mathrm{kDa}$ membrane treatment, the quality of the 
rubber glove wastewater is further improved. Hence, it is safer to be discharged into rivers.

Table 5 Comparison of rubber glove wastewater and membrane permeates (100 kDa and $10 \mathrm{kDa})$ to environmental discharge limit

\begin{tabular}{|c|c|c|c|c|}
\hline $\begin{array}{l}\text { Paramet } \\
\text { ers }\end{array}$ & $\begin{array}{l}\text { Rubb } \\
\text { er } \\
\text { glov } \\
\text { e } \\
\text { wast } \\
\text { e } \\
\text { wate } \\
\text { r }\end{array}$ & $\begin{array}{l}\text { Avera } \\
\text { ge } \\
\text { results } \\
\text { for } \\
\text { perme } \\
\text { ate } \\
\text { from } \\
100 \\
\mathrm{kDa}\end{array}$ & $\begin{array}{l}\text { Avera } \\
\text { ge } \\
\text { results } \\
\text { for } \\
\text { perme } \\
\text { ate } \\
\text { from } \\
10 \\
\mathrm{kDa}\end{array}$ & $\begin{array}{l}\text { Third } \\
\text { Schedule, } \\
\text { Environme } \\
\text { ntal } \\
\text { Quality } \\
\text { (Raw } \\
\text { Natural } \\
\text { Rubber) } \\
\text { Regulation } \\
\text { s, } \\
1978\end{array}$ \\
\hline $\begin{array}{l}\text { COD } \\
(\mathrm{mg} / \mathrm{L})\end{array}$ & $\begin{array}{c}71.2 \\
8 \\
\end{array}$ & 33.44 & 19.52 & 400 \\
\hline $\begin{array}{l}\text { TSS } \\
(\mathrm{mg} / \mathrm{L})\end{array}$ & $\begin{array}{c}68.0 \\
0\end{array}$ & 13.00 & 5.70 & 100 \\
\hline $\begin{array}{l}\mathrm{AN} \\
(\mathrm{mg} / \mathrm{L})\end{array}$ & $\begin{array}{c}22.0 \\
7\end{array}$ & 20.36 & 18.62 & 300 \\
\hline $\begin{array}{l}\mathrm{TKN} \\
(\mathrm{mg} / \mathrm{L})\end{array}$ & $\begin{array}{c}15.7 \\
1\end{array}$ & $\begin{array}{l}15.49 \\
\end{array}$ & $\begin{array}{l}14.79 \\
\end{array}$ & 300 \\
\hline $\begin{array}{l}\text { Turbidit } \\
\text { y } \\
\text { (NTU) }\end{array}$ & $\begin{array}{c}81.0 \\
0\end{array}$ & 4.83 & 2.84 & - \\
\hline $\mathrm{pH}$ & 8.00 & 8.00 & 7.99 & $6.0-9.0$ \\
\hline Colour & $\begin{array}{c}5 \\
\text { Haze } \\
n \\
\text { CAA } \\
\end{array}$ & $\begin{array}{c}2.5 \\
\text { Hazen } \\
\text { CAA }\end{array}$ & $\begin{array}{c}0 \\
\text { Hazen } \\
\text { CAA }\end{array}$ & - \\
\hline
\end{tabular}

Meanwhile, it can be clearly seen that $10 \mathrm{kDa}$ membrane successfully reduce COD, TSS, AN and TKN content of the rubber glove wastewater to be extremely below the permitted effluent limits of the regulation. $\mathrm{pH}$ is also within the tolerance range. In addition, it produced a much better quality of permeate as compared to 100 $\mathrm{kDa}$, hence it will be the least polluting to controlled watercourses. Thus, $10 \mathrm{kDa}$ PES membrane is indeed the better solution. But, if this laboratory-scale project is to be implemented on large scale in the industrial sector, various aspects need to be looked into, especially the cost-benefit analysis.

\section{CONCLUSION}

The flux versus time for $100 \mathrm{kDa}$ and $10 \mathrm{kDa}$ membranes were almost flat horizontal lines. The flux versus TMP (transmembrane pressure) for $100 \mathrm{kDa}$ and $10 \mathrm{kDa}$ membranes were linear.

$10 \mathrm{kDa}$ membrane produce higher quality of permeate as compared to $100 \mathrm{kDa}$ for parameters, that is, COD $(73.07 \%)$, TSS (90.61\%), AN (14.86\%), TKN (7.02\%) and turbidity $(96.60 \%)$.

Finally, ultrafiltration may not be so suitable to be used for trace metals rejections.

\section{REFERENCES}

1. http://mgcc.com.my/mgcc/main.nsf, 10/07/2004.

2. Sastry, C.A., Agamuthu, P. (2000). Removal of Zinc from Rubber Thread Manufacturing Industry Wastewater Using Chemical Precipitant/ Flocculant. Environmental Progress. 19(4): 299304.

3. Cheryan, M. (1998). Ultrafiltration and Microfiltration Handbook. Technomic Publishing Company.

4. Croll, B.T. (1992). Membrane Technology: The Way Forward? Water and Environmental Management. 6(2): 121-129.

5. Breslau, B.R., Buckley, R.G. (1995). Pall Filtron, Northborough, MA.

6. Ersu, C.B., Braida, W., Chao, K-P., Ong, S.K. (2004). Ultrafiltration of ink and latex wastewaters using cellulose membranes. Desalination. 164(1): 6370.

7. American Public Health Association (APHA). (1992). Standard Methods for Examination of Water and Wastewaters. $18^{\text {th }}$ Edition. American Public Health Association, Inc.

8. Bhattacharyya, D. (2001). Membranes and Environmental Applications. Environmental Progress. 20(1). A12. 